\title{
Slavery and power in Behn's Social Context; A New Historicist Reading of Oroonoko
}

\author{
Younes Poorghorban \\ MA Graduate of English Literature, Univrsity of Kurdistan, Iran.
}

DOI: http://doi.org/ 10.36892/ijlls.v2i4.427

$\begin{array}{ll}\begin{array}{l}\text { Received: } \\ \text { 04/11/2020 }\end{array} & \text { The aim of this article is to illustrate how power works within Behn's } \\ \text { Accepted: } & \text { Oroonoko in light of New Historicism. Behn's standpoint concerning slavery } \\ \text { 15/12/2020 } & \text { is quite unsettling, many arguments have been proposed concerning this issue. } \\ & \text { It is intended to shed light on how slavery is perceived for Behn and through } \\ & \text { her outlook, it becomes possible to illustrate how English colonialising power } \\ \text { Keywords: } & \text { acts in opposition to whatever that aims to subvert it. Discourse is a vehicle of } \\ \text { Aphra Behn, } & \text { power and in this paper, many discourses are analysed to depict the essence } \\ \text { Oroonoko, } & \text { of power. Language through discourses has managed to control and } \\ \text { New Historicism, } & \text { reproduce what is known as the truth. By shaping the truth in alliance to the } \\ \text { Power Relations, } & \text { dominant power it becomes possible to subvert and contain the opposing } \\ \text { Discourse. } & \text { resistance. This article illuminates how truth is shaped for the subjects of } \\ & \text { power (mainly Oroonoko and his Wife) by the proposed discourses of the } \\ & \text { narrator who is also considered as Behn herself. }\end{array}$

\section{INTRODUCTION}

A staunch supporter of the Stuart dynasty, a poet, a playwright, a translator, Aphra Behn was among the first English women who earned a living by writing. Throughout her works, she exhibited an "...image of court poet, dramatist to an aristocratic elite, and constant Royalist" (Todd, 2017, p. 37). Although her literary works signify a promising literary career, her short work of fiction, Oroonoko in particular, suggests her unique talents in the realm of prose. Oroonoko; or, the Royal Slave published a year before Behn's death which revolves around an African prince who is tricked and sold as a slave who rebels against British colonialism which eventually leads to his execution.

Many discussions concerning history and its validity have been shaped over the last few decades. Foucault under the influence of Nietzsche proposed a new outlook towards history which promotes the idea that history is always subjective and both history and the historian are under the influence of some particular ideologies. Therefore, achieving a just narration of what is in the past is almost impossible. In the 1980s, Stephen Greenblatt shaped a new critical approach called "New Historicism" by probing Foucauldian concepts such as power and discourse to bring about a less subjective picture of history by analysing literary works of that era. "Certainly, the presence of Michel Foucault on the Berkely campus... has helped to shape my own literary critical practice" (Greenblatt, 2007, p. 197). On the other hand, analysing the circulation of power and discourses help understanding how power works in certain contexts.

The present paper opens with a review of literature carried out by prominent scholars to illustrate reasoning concerning Behn's standpoint in relation to slavery. In the next section, the theoretical framework will be meticulously covered which is a wide explanation of New 
Historicism followed by key terms and the complete analysis of the novel based on the theoretical framework and the given terminology. The last section is the findings and conclusions proceeded by the list of references.

\section{LITERATURE REVIEW}

Oroonoko or the Royal Slave (1688) is Aphra Behn's highly known work for which she shall be eternally remembered. There is an abundant quantity of research on this short work of fiction, however, in this section, the researcher has modestly chosen some to elucidate some highly valuable research conducted on this short novel. Despite countless research done on the novel, barely has there been looked upon from a New Historicist viewpoint which suggests this work's originality.

The last scene of the novel where Oroonoko is brutally executed seems to busy the minds of many scholars. On one hand, the scene is horrifyingly depicted which galvanises the audience's sympathy. This deliberate agitating depiction signifies some sort of sympathy on the author's part as well. Yet, the question is whether this sense of sympathy counts for all other slaves or is only Oroonoko who gets to be dearly privileged. In a recent article entitled: "Dismembering the Sovereign in Aphra Behn's Oroonoko" (Griffin, 2019), the author analyses the scene to illuminate Behn's purpose for creating the scene explaining that she does not specifically object to slavery, rather she "objects to slavery-like conditions being illegitimately applied to certain groups of people" (p. 110). She fully justifies her argument by proposing that since Behn was a royalist, the last scene is a similar form of execution of a king and it is deplorable as such.

Many scholars are still concerned with whether Aphra Behn was an abolitionist or not. Trofimova in her "Direct style and rhetoric of freedom in Aphra Behn's Oroonoko" (2014) reaches the novel in a different approach. She analyses Oroonoko's major direct speeches and she concludes that at least, Oroonoko is against slavery while in fact, it is Oroonoko's who participates in slave trades. Her reasons simply fail to fully justify neither Behn's political views on slavery nor Oroonoko's anti-slavery mindset. Therefore, some of these direct speeches will later be analysed. These chosen direct speeches will be put in opposition to some other contexts related to the novel and the author as an endeavour to come to an end with this subject matter.

In 'Behn's Novel Investment in 'Oroonoko': Kingship, Slavery and Tobacco in English Colonialism" (1998), Iwanisziw shed light on a form of tobacco cultivated named "Oronoko". She explains that primarily, tobacco is a commodity brought to England, Europe, and North America. She later reasonably argues that Behn's use of the word Oroonoko for her hero ironically suggests that Oroonoko is indeed nothing but a commodity, a slave, a product, and eventually a narration who serves a noble deed. The noble purpose, however, is not an anti-slavery movement proposed by Behn, it is rather an outcry of "... Behn's support of the colonial enterprise under the direction of James II" (p. 83). She later clarifies: "Oroonoko's abused and fragmented corpse signifies a corrupt colonial administration which has undermined crown authority" (p. 83). The logical assumption of Iwanisziw is intentionally brought to serve to illuminate Behn's political views on slavery, moreover, it is intended to question whether Oroonoko can be considered as a commodity in the course of the novel.

Being a staunch monarchist, Aphra Behn's literary works have widely been influenced by her sense of royalism. Whether she was an abolitionist or a slavery supporter has been continuously argued by many scholars. What is undeniable is the fact that during the novel, the prince is vastly separated from other slaves and this, to some extent, relies on the fact that he is a prince. Pacheco in "Royalism and Honor in Aphra Behn's Oroonoko", (1994) attempted to illustrate the author's huge concern with the subject of royalism. She states: 
"This royalist discourse essentially portrays royal power as a natural law, suffused with divine purpose, residing in the blood of the legitimate royal line (p. 495)." African or European, what seemed to concern Behn at the time was enslaving a prince is almost heretical and gravely deplorable. It appears that during the novel, Behn slightly portrays any other slaves. What must not be forgotten, however, is that she shall not be looked upon poorly for having pro-slavery opinions since this is the mindset of the British empire in the period.

In "Oral and Literate Discourse in Aphra Behn's "Oroonoko" (1994), Paxman proposes two oppositional types through which discourses are presented, one is orality and the other one is literacy. He proves that literacy is the common form of discourse used by English power whereas, Orality was Oroonoko's common source of discourse. "The narrator's discourse undermines in a second way the attractions and powers of the oral Oroonoko" (p. 99). The written English form seems to subvert Orronoko's oral discourses. What Paxman appears to be ignorant of, however, is the fact that it is not only the matter of orality and literacy which cause power and resistance, rather it is through a network of compartments that one discourse comes to dominate the other. In this paper, it is presumed that literacy is the form of representing English discourses to better portray how truth is shaped.

\section{THEORETICAL FRAMEWORK}

\subsection{New Historicism}

New Historicism is a new approach to literary texts which burgeoned as a response to New Criticism, an approach which significantly focused on the text only. In this approach, however, a text ought to be read following the context. The context of a text is shaped by cultural, political, social, and historical facets. It must be stated that there is no specific theoretical background to the New Historicism rather our first glance at New Historicism is through the actual practice of the approach. As Greenblatt (2007), stated: "One of the peculiar characteristics of the 'new historicism' in literary studies is precisely how unresolved and in some ways disingenuous it has been" (p. 197). Therefore, it is quite difficult to limit New Historicism to better define it. This is an advantage as well as a disadvantage since it equally liberates the scholars to pursue every socio-political or even cultural theory to establish a just argument concerning history. Consequently, what is attempted to be illustrated in this article concerning the nature of power in Behn's Oroonoko does not only follow new historicist approach, however, it is intended to utilise critical standpoint of the Cultural Studies as well.

Being considerably undefined yet, some basic elements of New Historicism have been widely used which proposes a sort of stability in the definition of New Historicism and among which is the power relations. "New historicism is a mode of critical interpretation which privileges power relation as the most important context for texts of all kinds" (Brannigan, 1998, p. 6). The circulation of power must be sought in works of art since "the work of art is itself the product of a set of manipulations" (Greenblatt, 2007, p. 12). Greenblatt does not take art as an independent entity from social and cultural grounds, rather he considers texts as the cultural reproduction of the contexts and production of contexts caused by the production of the texts. "Cultural Poetics assumes that texts not only document the social forces that inform and constitute history and society but also feature prominently in the social processes themselves which fashion both individual identity and the sociohistorical situation" (Veenstra, 1995, p. 174). This assumption advocates that texts are not only affected by the context, rather they help creating and reproducing contexts as well. 
The significance of discourses in New Historicism is widely known since it is through discourses that power relations would be identified. Nevertheless, the ultimate purpose of New Historicism is sketching a less subjective history and to rewrite and equally appreciate history in accordance with the artistic works, a painting, a memoir, or a novel. "What interests Greenblatt is the whole complex of minute transactions that takes place between literature, culture, and society at the level of the text" (Kaes, 1992, pp. 151-152). Social practices are also elements through which New Historicists come to sketch history.

\subsection{Power}

In spite of New Historicism's resemblance in theory to that of Marxism on the basic grounds, the concept of power differs largely from that of Marxism. In Marxist theory, power is always in possession of the bourgeoisie and the ruling class in accordance with their benefits hegemonises all layers of society. This position of power to only one class of society does not apply to how power is perceived in New Historicism. New Historicists rely largely on Foucault's definition of power. "Power is everywhere; not because it embraces everything, but because it comes from everywhere" (Foucault, 1990, p.79). In this view, power circulates among all layers of society, it usually does so through discourses. "power is neither given, nor exchanged, nor recovered, but rather exercised, and that it only exists in action" (Foucault, 1988, p. 89). The circulation of power not only takes place by repressive state apparatuses but also through the shaping of what we know as Truth, through discourses. Discourses are a means of practicing power in its ideological grounds.

\subsection{Resistance}

The existence of power obliges a binary opposition which gives meaning to what power is and that is resistance. "Where there is power, there is resistance, and yet, or rather consequently, this resistance is never in a position of exteriority in relation to power" (Foucault, 1990 p. 81). It seems that the existence of power cannot be justified alone, rather it is resistance that makes it meaningful. "hegemonic power is necessary, or even possible, only because of resistance" (Fiske, 1997, p. 2). Resistance is practised in both ideological and repressive apparatuses. It is resistance which flows the circulation of power, by constantly and consistently producing and reproducing meaning in the battleground of discourses.

\subsection{Truth}

What is known as truth does not always account for what is objectively true, rather as Fiske puts it, it "can be written only by our vast institutional author that can mobilize all these voices and organize them in a hierarchy leading to a final knowledge of the truth that is greater than anyone of them, or than any other way of structuring them, because it produces a unified, continuous, uncontradictory common sense" (Fiske, 1997, p. 155). Consequently, everything we know as the ultimate truth is consistently under question since our perception of truth and reality is neither objective nor trustworthy anymore, it is a power-influenced reality which drastically alters our knowledge of everything. Fiske's theory concerning truth is tremendously affected by that of Foucault's. "The ultimate power for Foucault is the power of knowledge and social control is exercised through the control of knowledge or truth" (Fiske, 1997, p. 161). Resisting power, in this case, is at its most difficult since the subjects to the knowledge become dubious whether what they know is objectively true or if it is affected by the dominant power. Accordingly, identity crisis while encountering the dominant power tends to appear which either leads to a form of subversion or finds itself a powerful form of 
resistance. The representation of truth is one of the most significant vehicles in possession of power. By controlling and reproducing truth, power aims to create a hegemonic society.

\section{REPRESENTATION OF POWER AND BEHN'S ULTIMATE STANDPOINT CONCERNING SLAVERY}

What altered the worldview of a renaissance man towards life was an obsessive curiosity towards learning. In that era, knowledge became significantly important and the hunger for this knowledge seemed to be interminable. "the Renaissance, involved a rebirth of letters and arts stimulated by the recovery of texts and artifacts from classical antiquity" (Greenblatt, 2012, p. 534). Man became the centre of attention in that era leading to a radical presumption "that man was the measure of all things" (Greenblatt, 2012, p. 535), which is a system of value that privileges knowledge of man. This mindset comes as an opposition to ignorance of man, and Europe widely chose the path to knowledge. "And though they are all thus naked, if one lives forever among 'em there is not to be seen an indecent action, or glance: and being continually used to see one another so unadorned, so like our first parents before the Fall, it seems as if they had no wishes; there being nothing to heighten curiosity" (p. 74). This description is the very beginning of the novel where the narrator who's an English person from a different diversity comes to describe these people. It is before the beginning of the story and describing the main protagonist of the work.

The narrator describes these people as simple natured beings and she compares them with Adam and Eve before the fall. This comparison suggests that they were as innocent as Adam and Eve, however, this is only what it seems like. In order to clarify the major importance of this discourse a flash back to the Christian version of Adam and Eve is suggested. Adam and Eve were innocent in heaven, but innocence was not their only characteristics, they were also ignorant. "and the eyes of them both were opened, and they knew that they were naked" (Genesis 3:7 King James Version p. 8). It was only after they ate the fruit of the tree of knowledge that they became knowledgeable.

Behn opposes two different views, on one hand the innocence of the people which is considered worthy and on the other hand their ignorance which contradicts with British sense of knowledge. It is universally acknowledged that the western world preferred the path to knowledge by a more radical degree than the rest of the world. As Sir Francis Bacon stated, "for Knowledge is the image of existence" (Bacon, 1620/2009, p. 59), hence Behn meticulously brings about the English superiority in the discourse of knowledge, by proposing the natives ignorant of knowledge.

On the other hand, Behn's views on slavery are still a matter of analysis, considering what the narrator states as Behn's own viewpoint allows us to probe the descriptions she makes. The point she made as a characteristic of natives was their absolute innocence. "The Native Americans were, indeed, innocent, and their innocence suggested their fate to her: since like children they would be controlled and disciplined and she expected the corrupt Europeans to dominate them where they could" (Todd, 2017, p. 80). It seems that Behn's worldview suggested that where there is power, there must be some sort of domination. Moreover, she appears to consider these Natives inferior to the Europeans and worthy of slavery and domination as well.

The urge to limit any threat to the dominant power exists unconsciously in the mind of the narrator. She admires Oroonoko for the similarities she finds in him with the English culture. "He had nothing of barbarity in his nature, but in all points addressed himself as if his education had been in some European court. This great character of Oroonoko gave me an extreme curiosity to see him, especially when I knew he spoke French and English" (pp. 7778). In this part of the novel, the narrator portrays a better sketch of the character Oroonoko, 
who is the protagonist of the work who is also a prince. what he is being praised for intellectually is not some universal virtuous concepts, however, they are mostly related to the dominant English culture and the fundamental base on which the culture is set. He is being praised because no need of subversion or the changing of values is yet necessary. Another matter which he is being praised for is his ability to speak the dominant language. Language in itself is a mode of subversion, to prove this point a reference to Daniel Defoe's Robinson Crusoe (1719/2013) is needed: "In a little time, I began to speak to him; and teach him to speak to me: and first I let him know his name should be Friday, which was the day I saved his life: I called him so for the memory of the time. I likewise taught him to say Master" (p. 222).

In Robinson Crusoe, the protagonist teaches his subject the language and through the language, he creates a discourse to subjugate him. Merriam Webster defines master as "an individual or entity (as a corporation) having control or authority over another: as...the owner of a slave (Entry 1 of 2). This shows the role of language in the process of subversion, that without language changing a value system is almost impossible.

It appears that the admiration the narrator has for Oroonoko is not limited to his knowledge of the English language, rather it appears in the similarities she finds in his mien with the preferred taste of the dominant culture. "His nose was rising and Roman, instead of African and flat, his mouth the finest shape that could be seen, far from those great turned lips which are so natural to the rest of the negroes" (p. 78). Once more Oroonoko is being praised, though, this time it is not intellectual, but physical. The narrator is satisfied with his look because what she sees is very similar to a culturally praised English look. His nose is similar to those of Romans and his lips are thin. The criterion with which the character is being judged is also of the dominant culture. It is to be understood that every culture has a unique sense of beauty which shares with the society. It can be arguably stated that the narrator is trying to put Oroonoko in the English frame and concept of beauty and contain his physical appearance in the same dominant value. Whether she does so to affect the English audience's sympathy for her protagonist to stimulate their affection with the prince or not is a matter of analysis.

The dominant English power so far, has managed to enslave Oroonoko by the means of force. Although, this is not the only way that power is practised, the ideological way to subversion occurs normally before repressive apparatuses yet, in the case of Oroonoko, it appears that he is firstly enslaved by force and later ideological discourses are presented to him to completely subjugate him. "I ought to tell you that the Christians never buy any slaves but they give them some name for their own" (p. 101). The process of hailing soon appears when encountering slaves. This statement can be arguably applied to the British empire through colonialism and how they enslaved the Native Americans and Africans. Giving them their own names and making them speaking the language is reasonably considered as giving them a new identity. This description of approaches to slavery in British Islands offers a new insight to this heinous act.

The process of subversion has not yet fully been practised on Oroonoko and his wife. The narrator is involved in this process in many parts of the novel, the most notable one is when she states:

I entertained them with the loves of the Romans, and great men, charmed him to my company; and her, with teaching her all the pretty works that I was mistress of, and telling her stories of nuns, and endeavoring to bring her to the knowledge of the true God (p. 105).

This is the part of the novel where the narrator talks to Oroonoko and his wife. She again uses the Romans as a tool. It is the most significant value system that they are attached to, and on the other hand she wants to talk of "true God". The depth of all ideologies rooted 
in the creation of truth and knowledge. "Knowledge is power, and the circulation of knowledge is part of the social distribution of power" (Fiske, 1989 p. 149). In this sense, the narrator is practicing a social relationship of power in which religion is centred in this discourse. All the elements of power are at work to hegemonise Oroonoko and his wife.

So far, the dominant power has managed to restrain social practices in the controlled frame of society. It appears that little resistance exists among the slaves as if they have fully accepted their roles as slaves. Conversely, Oroonoko begins with a rebellious act of resistance when he gathers men and makes a speech:

'And why,' said he, 'my dear friends and fellow sufferers, should we be slaves to unknown people? Have they vanquished us nobly in fight? Have they won us in honourable battle? And are we by the chance of war, become their slaves? This would not anger a noble heart, this would not animate a soldier's soul. No, but we are bought and sold like apes, or monkeys to be the sport of women, fools and cowards, and the support of rogues and runagades (p. 116).

The speech that Oroonoko makes infuriates many slaves and forms a sense of resistance which can no longer be kept in a form of an ideology rather, it causes drastic actions of rebellion to conquer the British slavers. On the other hand, Oroonoko, Behn's hero seems to be justifying other ways of slavery which proposes Behn's actual stand where the strong dominates the weak. It can be arguably stated that Behn believes in some sort of just slavery among which tricking a prince is not accepted, and as Spencer (2001), stated: "Most recent discussions of the novel are united in finding that the narrative condemns not slavery per se, but the enslaving of a prince" (p. 225). The fierce rebellious act which Oroonoko causes ends shortly after when the other slaves stop supporting Oroonoko, hapless and enraged with his situation he makes another speech when he is captured by the British power explaining that "he was ashamed of what he had done, in endeavouring to make those free, who were by nature slaves" (p. 120). Once more Oroonoko asserts that some people are innately slaves, which does not propose any sort of anti-slavery opinions rather, it confirms slavery for some people. The narrator as well seems to be sympathetic during the course of novel with Oroonoko.

The last scene of the novel is described in details which depicts a daunting scene of torture and pain. Oroonoko has already murdered his pregnant wife and he is now waiting for his execution. "He had learned to take tobacco, and when he was assured that he would die, he desired that they would give him a pipe in his mouth" (p. 128). Tobacco is of course a commodity, this commodity originally belonged to the Natives but the way that European used it with their pipes was quite different from how Natives used it. This function of such commodity being used as a social practice in a European sense at the last scene of the novel, suggests that the process of subversion has partially taken place even for Oroonoko, and he is now using a commodity of the dominant power as he slowly dies. On the other hand, Oroonoko himself cannot be considered as a commodity, it is undeniable that as a slave he could be some sort of commodity, yet, his constant resistance which reached its utmost state when he killed his pregnant wife proposes his ultimate resistance which is unaccepted from a commodity.

\section{CONCLUSION}

This paper claims that Aphra Behn was not against slave-trade institution. By bringing some examples from the text and also from the biographies of Behn it can be reasonably argued that she is far from being an anti-slavery activist and her mere concern with Oroonoko is because of his position as a prince. If he was not a prince, Behn would not create such dramatic effects in this story. Through the novel, the exercise of power is portrayed to illustrate how the circulation of power works. Oroonoko, as an opposition to the 
dominant power failed to overthrow the institution of slavery which led to his frightening execution at the end of the novel. The shaping of truth and of knowledge was another issue that was practised in the novel by the subjects of the dominant power and that eventually led to some sort of subversion even for the protagonist, Oroonoko. On the other hand, Behn helps us understand how the process of slavery takes place in English colonialism which is as well portrayed by the narrator. The urge to restrain and contain the protagonist exists even in the narrator and she does her best to make the process occur by introducing many discourses and among which is the religious discourse when she claimed to be talking of the "True God". Another issue which was depicted in the paper was constant efforts of the protagonist as a form of resistance against the dominant power which culminated in killing his pregnant wife, yet, and on the contrary, Oroonoko's use of Tobacco at the last scene of the novel proved that he was at least to some extent subjected to the dominant ideology and the process of containment has partially taken place.

\section{REFERENCES}

Bacon, F. (2009). The new organon, or true directions concerning the interpretation of nature. Gloucestershire, England: Dodo Press.

Behn, A., \& Todd, J. (1992). Oroonoko. The Rover. London: Penguin.

Brannigan, J. (1998). New historicism and cultural materialism. Houndmills: Macmillan.

Defoe, D., \& Brock, H. M. (2013). The life and adventures of Robinson Crusoe. UK: Ancient Wisdom Publications.

FISKE, J. (1997). Reading the popular. London: Routledge.

Foucault, M., \& Gordon, C. (1980). Power/knowledge: Selected interviews and other writings, 1972-1977. New York: Pantheon Books.

Foucault, M., \& Hurley, R. J. (1990). The history of sexuality. New York: Vintage.

Greenblatt, S. (2007). Learning to curse: Essays in early modern culture; Routledge, Taylor and Francis Group.

Greenblatt, S., \& Abrams, M. H. (2012). The Norton anthology of English literature. New York, NY: Norton.

Griffin, M. (2019). Dismembering the Sovereign in Aphra Behn's Oroonoko. ELH 86(1), 107-133. doi:10.1353/elh.2019.0004.

Iwanisziw, S. (1998). Behn's Novel Investment in "Oroonoko": Kingship, Slavery and Tobacco in English Colonialism. South Atlantic Review, 63(2), 75-98. doi: $10.2307 / 3201039$

Kaes, A. (1992). New Historicism: Writing Literary History in the Postmodern Era. Monatshefte, 84(2), 148-158. Retrieved November 20, 2020, from http://www.jstor.org/stable/30161347

Merriam-Webster. (n.d.). Master. In Merriam-Webster.com dictionary. Retrieved November 20, 2020, from https://www.merriam-webster.com/dictionary/master 
Pacheco, A. (1994). Royalism and Honor in Aphra Behn's Oroonoko. Studies in English Literature, 1500-1900, 34(3), 491-506. doi:10.2307/450878

Paxman, D. (1994). Oral and Literate Discourse in Aphra Behn's "Oroonoko". Restoration: Studies in English Literary Culture, 1660-1700, 18(2), 88-103. Retrieved November 20, 2020, from http://www.jstor.org/stable/43293587

Spencer, J. (2001). Aphra Behns afterlife. Oxford: Oxford Univ. Press.

Todd, J. (2017). Aphra Behn: A secret life. London: Fentum Press.

Veenstra, J. (1995). The New Historicism of Stephen Greenblatt: On Poetics of Culture and the Interpretation of Shakespeare. History and Theory, 34(3), 174-198. doi: $10.2307 / 2505620$

Трофимова, В. (2014). Direct Style and Rhetoric of Freedom in Aphra Behn's Oroonoko. Procedia - Social and Behavioral Sciences. 158. 383-388. 10.1016/j.sbspro.2014.12.104.

\section{$\underline{\text { AUTHORS' BIOS }}$}

Younes Poorghorban is an MA graduate of English Literature from university of Kurdistan, Iran. His interests are particularly, Victorian literature, Cultural Studies, New Historicism, Post colonialism, and Marxism. He graduated from Razi University for his Bachelor's degree and he is currently doing research related to cultural studies. Poorghorban's previous academic article was a New Historicist study of Widower's House by George Bernard Shaw. 